\title{
Evaluation of Loop-Mediated Isothermal Amplification for the Detection of Salmonella from Poultry Matrices
}

\author{
Raj Rajagopal $^{1, *}$, Gabriela Lopez-Velasco ${ }^{1}$, John M. David ${ }^{1}$, Melissa Sisemore ${ }^{2}$, Jamie Goseland ${ }^{2}$ \\ ${ }^{1} 3 \mathrm{M}$ Food Safety, 3M Company, St. Paul, MN 55144, USA. \\ ${ }^{2}$ WBA Analytical Laboratories, Inc., Springdale, AR 72762, USA.
}

How to cite this paper: Raj Rajagopal, Gabriela Lopez-Velasco, John M. David, Melissa Sisemore, Jamie Goseland. (2021) Evaluation of Loop-Mediated Isothermal Amplification for the Detection of Salmonella from Poultry Matrices. International Journal of Food Science and Agriculture, 5(4), 717-727.

DOI: $10.26855 /$ ijfsa.2021.12.020

Received: November 4, 2021

Accepted: November 27, 2021

Published: December 10, 2021

*Corresponding author: Raj Rajagopal, 3M Food Safety, 3M Company, St. Paul, MN 55144, USA.

Email: bsrajagopal@mmm.com

\begin{abstract}
Loop-mediated isothermal amplification (LAMP) has emerged as an alternative to PCR based methods for detection of food-borne pathogens, offering simple, easy to use, detection technology with high speed, efficiency, sensitivity and specificity. The performance of LAMP-bioluminescent assay as an alternative method for the detection of Salmonella in primary production samples, poultry rinses and raw poultry products compared to PCR was evaluated. After enrichment, boot swabs from poultry farms, carcass rinses and raw poultry products were tested by a LAMP-bioluminescent and a PCR assay. The LAMP-bioluminescent assay was able to detect Salmonella in the various matrices tested and had higher or equivalent sensitivity and specificity to the PCR method used. No significant difference (95\% confidence interval) was found between the LAMP and PCR method as determined by probability of detection analysis. The Salmonella LAMP-bioluminescent assay enabled reliable and rapid detection of Salmonella in variety of poultry matrices and is an acceptable alternative to the PCR method.
\end{abstract}

\section{Keywords}

Salmonella, isothermal amplification, LAMP, poultry, PCR

\section{Introduction}

Salmonella is globally recognized as a major cause of foodborne infection in humans. About 1.35 million illnesses occur each year in the US due to salmonellosis and food is the source of most of this illnesses [1] resulting in significant economic burden [2, 3]. Salmonella is a significant problem in the poultry industry throughout the world [4, 5]. Raw poultry products are contaminated with Salmonella and Campylobacter due to rupturing of contaminated gut contents (small intestine and ceca) during slaughter operations [4, 6]. In addition, contamination of bird's feathers and skin in the farm can bring these bacteria to the processing facilities [4]. Proper sanitary operations and use of antimicrobial interventions are necessary to minimize the contamination during slaughter and processing of the carcasses into parts and comminuted products. Government agencies, such as the US Department of Agriculture (USDA) Food Safety and Inspection Service (FSIS), have implemented pathogen reduction performance standards for Salmonella and Campylobacter in raw chicken parts, ground chicken and ground turkey [7, 8]. Performance standards are used by the USDA FSIS to assess establishment performance for various poultry products. Recently, USDA announced plans to mobilize a stronger and more comprehensive efforts to reduce Salmonella illnesses associated with poultry products with a goal to achieve the national target of a 25\% reduction in Salmonella illnesses [9]. These efforts have necessitated continued and increased surveillance of Salmonella in the poultry industry. While the advances in rapid methods such as immunoas- 
says and PCR have enabled accurate detection of foodborne pathogens [10-14], there is still a need for a quicker, simpler and less expensive technology.

Loop-mediated isothermal amplification (LAMP) can amplify DNA under isothermal conditions (60 to $\left.65^{\circ} \mathrm{C}\right)$ with high specificity and sensitivity in 60 min or less [15-18]. The DNA amplification is driven by Bst polymerase, a unique enzyme with DNA strand-displacement activity that enables the continuous, rapid isothermal amplification of DNA. LAMP uses multiple primers to recognize distinct regions of the genome and Bst DNA polymerase to provide continuous and rapid amplification of genetic material [15-18]. Compared to PCR, LAMP performs better as it has greater ability to amplify DNA in the presence of interfering substances often found in clinical, food and environmental samples [19-24]. LAMP has been coupled to a bioluminescent assay for the detection of amplified products, enabling simultaneous detection and amplification which provides real-time results and a short run time [25]. The LAMP-bioluminescent method offers a simpler, faster and streamlined approach to pathogen detection [26-33]. The Salmonella LAMP-bioluminescent assay, $3 \mathrm{M}^{\mathrm{TM}}$ Molecular Detection Assay 2 - Salmonella (MDA2SAL96) has been used for the detection of Salmonella in a variety of food matrices [26-33] and is equivalent to standard culture methods.

The objective of this study was to evaluate the performance of a Salmonella LAMP-bioluminescent assay for the detection of Salmonella in poultry rinses and raw poultry products as compared to a PCR assay. Salmonella LAMP assay was also evaluated for detection of Salmonella in primary production samples (boot swabs) as compared to the US National Poultry Improvement Plan (NPIP) method [34].

\section{Materials and methods}

The enrichment conditions for both the LAMP (MDA2SAL96, 3M Food Safety, St. Paul, MN) and the PCR method (BAX ${ }^{\circledR}$ System PCR assay for Salmonella, Hygiena LLC, Camarillo, CA) for various matrices are summarized in Table 1. The samples were enriched per recommended protocol (Table 1) and analyzed by the LAMP method (MDA2SAL96) or the PCR method (BAX® System PCR assay for Salmonella). For all samples analyzed with LAMP-bioluminescent assay, randomly selected samples were also analyzed with the external amplification control, $3 \mathrm{M}^{\mathrm{TM}}$ Molecular Detection Matrix Control (3M Food Safety), to assess sample interference during the amplification reaction. All samples analyzed by both molecular method were culture confirmed as outlined in Figures 1-3. Total aerobic counts in all matrices were also determined by serially diluting the sample homogenates in Butterfield's phosphate buffer (3M Food Safety) and plating on $3 \mathrm{M}^{\mathrm{TM}}$ Petrifilm ${ }^{\mathrm{TM}}$ Aerobic Count Plates (3M Food Safety). The plates were incubated for 48 hours at $35 \pm 1^{\circ} \mathrm{C}$ and colonies were enumerated.

Table 1. Sample preparation and enrichment protocols for Salmonella detection

\begin{tabular}{|c|c|c|c|c|c|c|c|}
\hline Sample matrix & Sample size & $\begin{array}{c}\text { Enrichment } \\
\text { medium }\end{array}$ & $\begin{array}{l}\text { Enrichment } \\
\text { temperature } \\
\quad\left( \pm 1^{\circ} \mathrm{C}\right)\end{array}$ & $\begin{array}{l}\text { Enrichment } \\
\text { time (hours) }\end{array}$ & $\begin{array}{l}\text { Enrichment } \\
\text { medium }\end{array}$ & $\begin{array}{l}\text { Enrichment } \\
\text { temperature } \\
\quad\left( \pm 2^{\circ} \mathrm{C}\right)\end{array}$ & $\begin{array}{l}\text { Enrichment } \\
\text { time (hours) }\end{array}$ \\
\hline & & \multicolumn{3}{|c|}{ MDA2SAL96 } & \multicolumn{3}{|c|}{ BAX ${ }^{\circledR}$ System PCR assay for Salmonella } \\
\hline $\begin{array}{l}\text { Whole bird carcass or } \\
\text { parts rinsed in } 400 \\
\text { mL of BPW }\end{array}$ & $\begin{array}{l}30 \mathrm{~mL} \text { of } \\
\text { rinsate }\end{array}$ & $30 \mathrm{~mL}$ BPW ISO & 41.5 & $18-24$ & $30 \mathrm{~mL}$ BPW & 35 & $20-24$ \\
\hline Raw poultry products & $325 \mathrm{~g}$ & $\begin{array}{c}975 \mathrm{~mL} \\
\text { (pre-warmed) } \\
\text { BPW ISO }\end{array}$ & 41.5 & $14-24$ & $\begin{array}{c}\text { 1,625 mL } \\
\text { BPW }\end{array}$ & 35 & $20-24$ \\
\hline $\begin{array}{l}\text { NPIP method } \\
\text { Boot swabs from } \\
\text { primary production }\end{array}$ & 1 boot swab & $\begin{array}{c}100 \mathrm{~mL} \mathrm{TT} \\
\text { broth }\end{array}$ & 37 & $20-24$ & & & \\
\hline
\end{tabular}

\subsection{Preparation of Salmonella inoculum}

Three Salmonella isolates were used in this study, Salmonella enterica Heidelberg (ATCC 8326), Salmonella enterica Senftenberg (ATCC 43845), and wild isolate Salmonella enterica Enteritidis. The ATCC strains were obtained from ATCC, Manassas, VA and the wild isolate was from the culture collection of WBA Analytical Laboratories, Springdale, AR. To prepare a cocktail of Salmonella inocula, an isolated colony from tryptic soy agar (TSA, Edge Biologicals, Memphis, TN) was inoculated into $10 \mathrm{~mL}$ of Brain Heart Infusion Broth (BHI, Becton Dickinson, Franklin Lakes, NJ) using a sterile inoculating loop and incubated for 18 hours at $35^{\circ} \mathrm{C}$. After incubation, all three BHI tubes were combined in one sterile $50 \mathrm{ml}$ centrifuge tube and centrifuged at $5000 \mathrm{xg}$ for $15 \mathrm{~min}$ at $6^{\circ} \mathrm{C}$. The pellets were washed twice with $30 \mathrm{~mL}$ of sterile $0.85 \%$ saline and resuspended in $0.85 \%$ saline. Serial 10 -fold dilutions of suspensions were prepared in $0.85 \%$ saline and 100 microliter of the dilutions was spread plated on TSA and incubated at $35^{\circ} \mathrm{C}$ for 18 hours. The 
colonies on TSA plates were counted, and an average count of each dilution was used to determine appropriate amount of inoculum added to each sample.

\subsection{Primary production samples}

\subsubsection{Boot swabs}

Thirty samples of boot swabs were collected in two farms ( $\mathrm{n}=30 /$ farm for a total of 60 samples) for Salmonella testing using sterile boot swab (cotton-poly blend fabric sock style boot cover) pre-moistened with double-strength skim milk (Solar Biologics Inc., Massena, NY). Briefly, a technician placed disposable plastic boot cover over the shoes to protect personal clothing and prevent cross contamination of the sample from shoe sole carryover. Then technician removed a sterile pre-moistened boot swab from the twirl-tie bag and placed over the boot cover and walked the entire length of one side of the poultry house. After sample collection, the boot swab was removed, immediately transferred to the original twirl-tie bag and transported to the the laboratory for further processing. One hundred mL of sterile TT broth (Edge Biologicals) was added to each of the bags. All the boot swabs were incubated at $37^{\circ} \mathrm{C}$ for 22 hours. The flow chart for detection of Salmonella in boot swabs is shown in Figure 1.

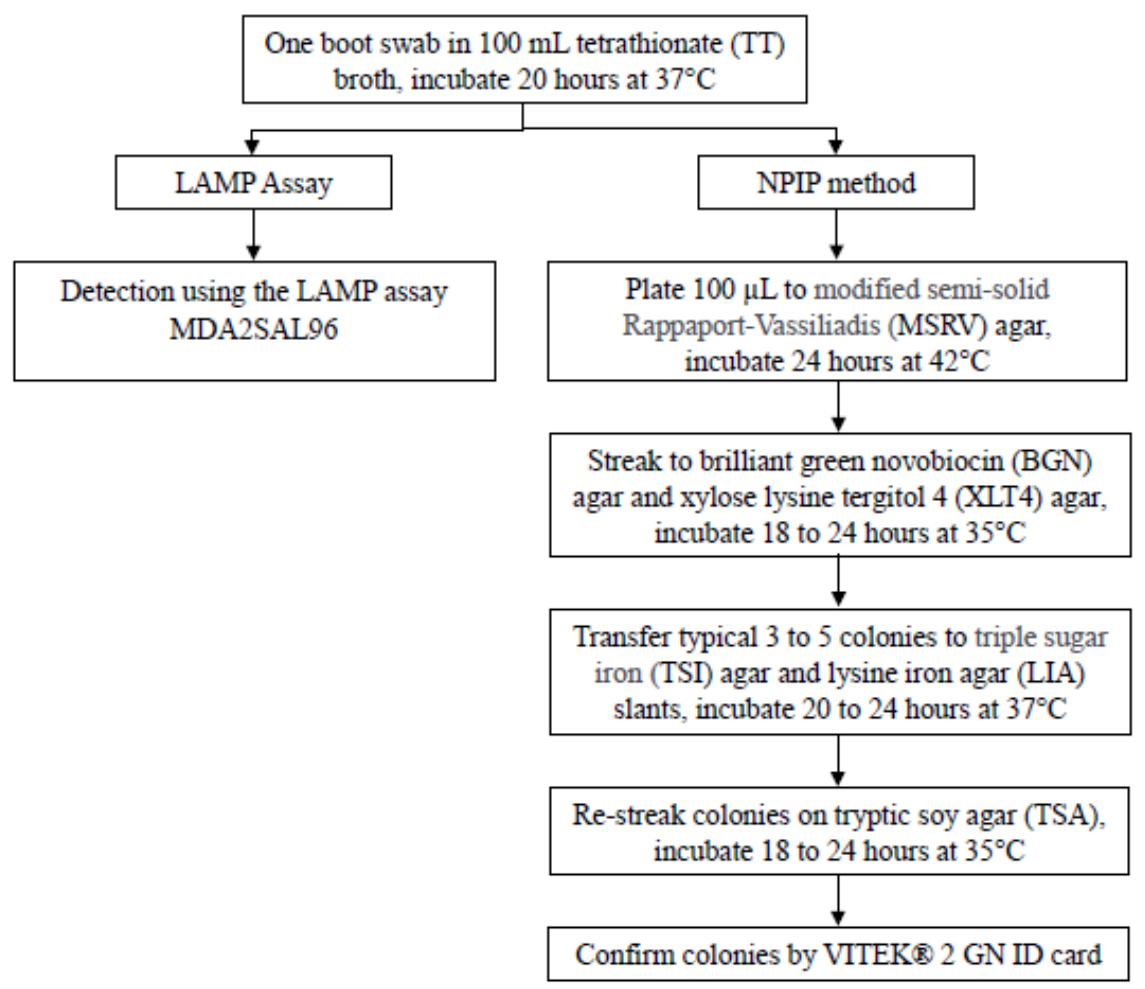

Figure 1. Flow chart for detection of Salmonella in primary production boot swabs by MDA2SAL96 and NPIP method.

\subsection{Poultry sample collection}

Whole chicken carcass rinsates and raw poultry products were collected from a commercial broiler abattoir. The samples were collected from the processing line at three sampling points (rehang, post-chill intervention and poultry parts processing).

\subsubsection{Rinsate collection}

Carcasses were collected from the poultry processing line, allowed to drain for at least 1 minute and aseptically transferred into a sterile poultry rinse bag (Nasco, Fort Atkinson, WI). A total of $400 \mathrm{~mL}$ of cold (kept at 2-8 $8^{\circ} \mathrm{C}$ ) buffered peptone water (BPW) (3M Food Safety) was added to each bag by pouring approximately half of the solution into the interior cavity and half onto the exterior of the carcass. The bag was closed to prevent leakage and the carcass or parts were rinsed by gently shaking for 1 minute using a 1-foot arm-arcing motion. The rinsate was aseptically transferred back into the original container, capped tightly and labeled with sample information. Rinsates were then transported in a cooler with ice to the laboratory and used for further testing. 


\subsubsection{Rinsate testing}

BPW rinsates were evaluated in an unpaired study to compare the LAMP method for detection of Salmonella against the PCR method. The flow chart for detection of Salmonella in rehang and post-chill rinsates is shown in Figure 2. A total of 120 rinsates, 30 rinsates from rehang carcasses and 30 rinsates from post-chill carcasses for each method were analyzed for Salmonella detection (total of 60 rinsates for each method).

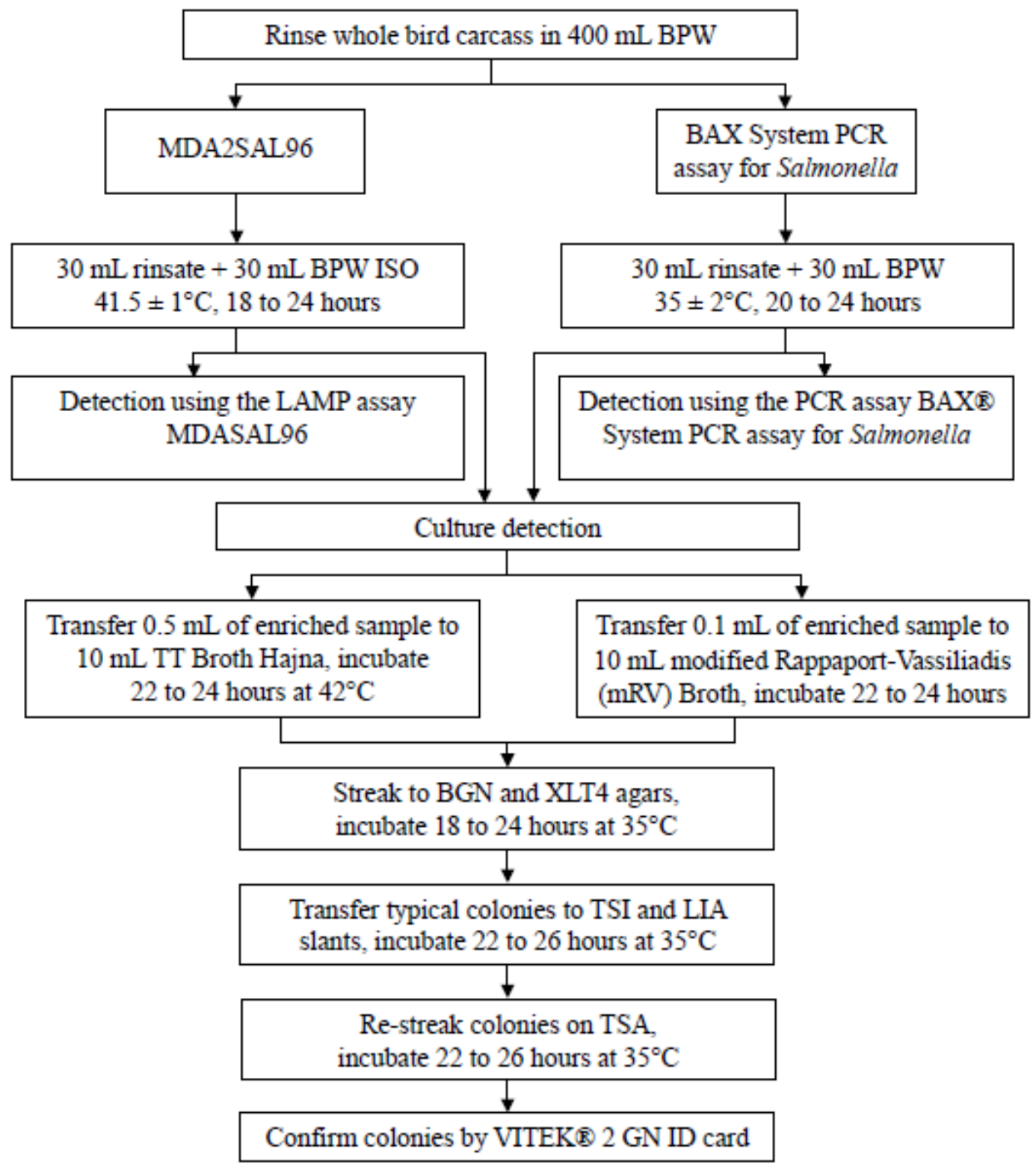

Figure 2. Flow chart for detection of Salmonella in poultry carcass or parts rinse by MDA2SAL96 and PCR method and culture confirmation.

For each of the method, $30 \mathrm{~mL}$ of the rinsate was added to a sterile Samco ${ }^{\mathrm{TM}}$ Narrow Mouth Bio-Tite ${ }^{\mathrm{TM}} 90 \mathrm{~mL}$ specimen containers (Thermo Fisher Scientific, Rochester, NY) and processed for enrichment as follows. Ten rehang carcass rinsates and ten post-chill carcass rinsates were set up as controls (uninoculated) to screen for natural contamination. Twenty rehang carcass rinsates and twenty post-chill carcass rinsates were inoculated with $100 \mu \mathrm{L}$ of bacterial suspension, described above, at 1 to 2 CFU per $30 \mathrm{~mL}$ of rinsates. Each of the control and inoculated rinsate was then combined with $30 \mathrm{~mL}$ of BPW ISO for the LAMP method and $30 \mathrm{~mL}$ of BPW for the PCR method. The samples were gently mixed and incubated at $41.5^{\circ} \mathrm{C}$ for 18 hours for the LAMP method and at $35^{\circ} \mathrm{C}$ for 20 hours for the PCR method (Table 1). 


\subsubsection{Raw poultry product preparation}

An unpaired study was done to compare the detection of Salmonella in raw poultry products (Figure 3) by the LAMP-bioluminescent assay and PCR method. Twelve types of raw products were utilized in this study. Using a pre-heated bead sterilizer and metal cutting utensils, ten $325 \mathrm{~g}$ samples were cut from each product type. The products were added to a $4 \mathrm{~L}$ sterile Whirl-Pak filter bag (Nasco, Fort Atkinson, WI). Two to three samples out of 5 samples for each product type was used to screen for natural contamination and the rest was inoculated with $100 \mu \mathrm{L}$ of Salmonella suspension, described above, at 1 to $2 \mathrm{cfu} / 325 \mathrm{~g}$ test portion, and then stored at $4-8^{\circ} \mathrm{C}$ for 24 hours before enrichment.

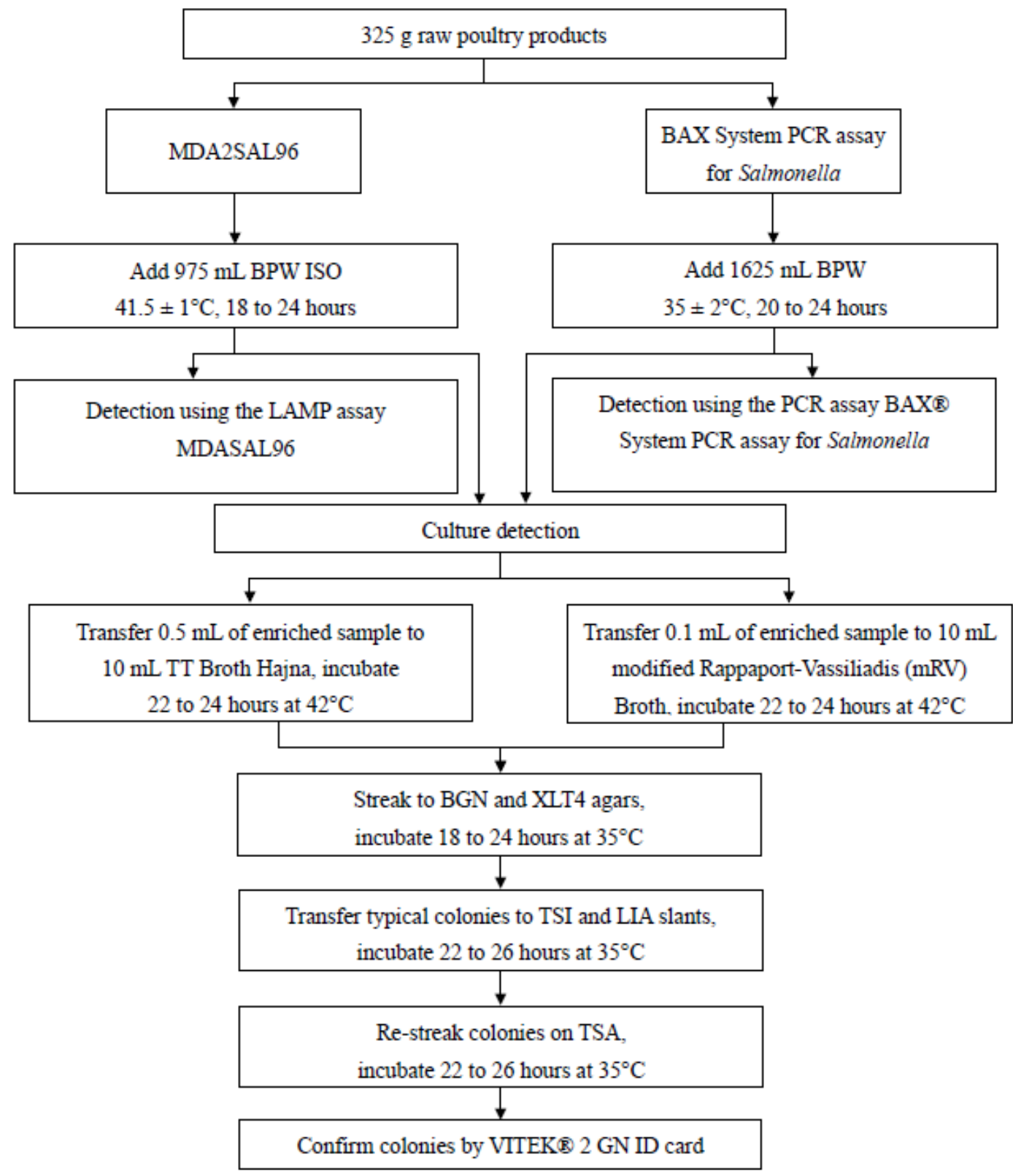

Figure 3. Flow chart for detection of Salmonella in raw poultry products by MDA2SAL96 and PCR method and culture confirmation.

\subsubsection{Raw poultry product testing}

For LAMP method, $325 \mathrm{~g}$ of sample (uninoculated or artificially contaminated) in a $4 \mathrm{~L}$ sterile Whirl-Pak filter bag (Nasco) was combined with $975 \mathrm{~mL}$ of BPW ISO, homogenized in a stomacher (Stomacher 3500, Seward Laboratory Systems Inc., Port Saint Lucie, FL) for 30 seconds and incubated at $41.5^{\circ} \mathrm{C}$ for 14 hours (Table 1).

For PCR method $325 \mathrm{~g}$ of sample (uninoculated or artificially contaminated) in a $4 \mathrm{~L}$ sterile Whirl-Pak filter bag 
(Nasco) was combined with 1,625 mL of BPW, homogenized in a stomacher (Seward Laboratory Systems Inc.) for 30 seconds and incubated at $35^{\circ} \mathrm{C}$ for 20 hours (Table 1 ).

\subsection{Salmonella detection}

For the LAMP assay, $20 \mu \mathrm{L}$ of sample after enrichment in BPW ISO (poultry rinsates and parts) or TT broth (boot swabs) was collected and processed for detection using the 3M ${ }^{\mathrm{TM}}$ Molecular Detection System following manufacturer's instructions (3M Food Safety). For the PCR method, samples (poultry rinsates and parts) were analyzed after enrichment in BPW by the BAX ${ }^{\circledR}$ System PCR assay for Salmonella assay following manufacturer’s instructions.

Regardless of the presumptive results obtained by the two methods, primary enrichments from both the LAMP and the PCR method were culture-confirmed per the USDA FSIS Microbiology Laboratory Guidebook (MLG) 4.11 Culture reference method [35] with some modifications (Figures 2, 3). For boot swabs, TT broth enrichments were confirmed following NPIP method (Figure 1).

\subsection{Analysis of results}

The alternative method results (presumptive results) were compared to the culture method to determine false positive and false negative rates [36]. Presumptive results obtained for both carcass rinsates and raw poultry products for Salmonella detection with the LAMP and the PCR method were compared with the confirmed culture results and sensitivity (false negative rate) and specificity (false positive rate) [36] was calculated using equation 1 and 2, respectively.

$$
\begin{aligned}
& \text { Sensitivity }=\frac{\text { Number of true positives }}{\text { Number of true positives }+ \text { Number of false negatives }} X 100 \\
& \text { Specificity }=\frac{\text { Number of true negatives }}{\text { Number of true negatives }+ \text { Number of false positives }} X 100
\end{aligned}
$$

True positives: culture-confirmed positive results

True negatives: culture-confirmed negative results

False negatives: presumptive negative results, positive culture results

False positives: presumptive positive results, negative culture results

For rinsate and product samples, Probability of Detection (POD) was computed for both the LAMP method (POD LAMP, $\mathrm{POD}_{2}$ ) and the PCR method (POD PCR, $\mathrm{POD}_{1}$ ) and used as a statistical model to validate LAMP method [37]. POD was calculated as the ratio of number of positives to total number of samples tested for each method at each analyte concentration. dPOD, the differential between the probability of detection (POD) for the LAMP method $\left(\mathrm{POD}_{2}\right)$ and the POD for the PCR method $\left(\mathrm{POD}_{1}\right)$ was computed. The lower and upper confidence limit $(95 \%$ confidence interval) for $\mathrm{POD}_{1}$ and $\mathrm{POD}_{2}$ was calculated and used to calculate the lower and upper limit for $\mathrm{dPOD}$ [37]. If the confidence interval of a dPOD does not contain zero, then the difference is statistically significant at the 5\% level [37].

\section{Results}

\subsection{Primary production samples}

The boot swabs were not artificially inoculated as natural contamination was prevalent in the samples. Detection of Salmonella in naturally contaminated boot swabs showed different prevalence of Salmonella in the two sampled farms: 8 and 25 positives out of 30 samples were determined from farms A and B, respectively by the LAMP method. Presumptive results from the LAMP method were all culture confirmed and in total agreement with the NPIP method (Table 2).

\begin{tabular}{|c|c|c|c|}
\hline \multirow{2}{*}{ Boot swabs $^{a}$} & \multirow{2}{*}{ Number of boot swabs } & \multicolumn{2}{|c|}{ Number of positive samples } \\
\hline & & Presumptive result ${ }^{\mathrm{b}}$ & Culture Confirmed result ${ }^{\mathrm{C}}$ \\
\hline & & MDA2SAL96 & \\
\hline Natural contamination (Salmonella) & 30 & 8 & 8 \\
\hline Natural contamination (Salmonella) & 30 & 25 & 25 \\
\hline
\end{tabular}

Table 2. Detection of Salmonella in primary production boot swabs

${ }^{a}$ Average background aerobic flora varied from 7.7 to $9.38 \mathrm{Log}$ cfu/mL.

${ }^{b}$ Number of positive samples detected by the LAMP method, MDA2SAL96.

${ }^{\mathrm{c}}$ All samples were culturally confirmed using NPIP method for Salmonella (Figure 1). 


\subsection{Carcass rinsates}

\subsubsection{Salmonella detection in Rehang carcass rinsates}

The average background aerobic flora in rehang rinsate was about $4.4 \mathrm{Log}$ cfu/mL. Natural contamination of Salmonella was detected in 1 out of 10 rehang rinsates by the LAMP method and in 2 out of 10 rehang rinsates by the PCR method. For the 20 inoculated rinsate samples, Salmonella was detected in 18 samples analyzed with the LAMP method and in 17 samples for the PCR method (Table 3). Two confirmed samples could not be detected by the LAMP method and three samples by the PCR method. In addition, PCR method had one unconfirmed presumptive result. The sensitivity of the LAMP assay, was $91.3 \%$ and $87.5 \%$ for the PCR method. Specificity was $100 \%$ for the LAMP method and $90 \%$ for the PCR method.

In the initial culture screening from the rehang samples, four presumptive positive samples from the LAMP method and three presumptive positive samples from the PCR method were considered to be potential "false positives" as atypical characteristic colonies were seen on selective Salmonella agar. The presumptive positives were restreaked on several BGS and XLT4 agar and up to three additional typical and atypical colonies were collected from Salmonella selective agar for biochemical identification. With additional colony identification, presumptive positive samples were confirmed as Salmonella. Some of the atypical colonies were identified as Escherichia coli, Proteus mirabilis, Klebsiella pneumoniae and Citrobacter freundii.

\subsubsection{Salmonella detection in Post-chill carcass rinsates}

The average background aerobic flora in post-chill rinsates was about $2.28 \mathrm{Log}$ cfu/mL. No natural Salmonella contamination was detected in any of the control (uninoculated) samples, while Salmonella was detected in 19 out of the 20 rinsates analyzed for both methods. Presumptive results obtained by both the methods were in $100 \%$ agreement with culture confirmation results (Table 3). The sensitivity and specificity of both the methods for the post-chill rinsates was $100 \%$.

Table 3. Comparison between the LAMP assay and the PCR method for the detection of Salmonella in carcass rinsates

\begin{tabular}{|c|c|c|c|c|c|c|}
\hline Rinsate $^{a}$ & $\begin{array}{c}\text { Number of } \\
\text { rinsates }\end{array}$ & $\begin{array}{l}\text { Presumptive } \\
\text { result }^{\mathrm{b}}\end{array}$ & $\begin{array}{c}\text { Culture } \\
\text { Confirmed result }^{\mathrm{c}}\end{array}$ & $\begin{array}{c}\text { Number of } \\
\text { rinsates }\end{array}$ & $\begin{array}{l}\text { Presumptive } \\
\text { result }^{\mathrm{b}}\end{array}$ & $\begin{array}{c}\text { Culture } \\
\text { Confirmed result }^{\mathrm{c}}\end{array}$ \\
\hline Rehang carcass & \multicolumn{3}{|c|}{ MDA2SAL96 } & \multicolumn{3}{|c|}{ BAX ${ }^{\circledR}$ System PCR assay for Salmonella } \\
\hline Natural contamination & 10 & 1 & 1 & 10 & 2 & 1 \\
\hline Salmonella $^{\mathrm{d}}$ & 20 & 18 & 20 & 20 & 17 & 20 \\
\hline Total & 30 & 19 & 21 & 30 & 19 & 21 \\
\hline \multicolumn{7}{|l|}{ Post-chill carcass } \\
\hline Natural contamination & 10 & 0 & 0 & 10 & 0 & 0 \\
\hline Salmonella $^{\mathrm{d}}$ & 20 & 19 & 19 & 20 & 19 & 19 \\
\hline Total & 30 & 19 & 19 & 30 & 19 & 19 \\
\hline
\end{tabular}

${ }^{a}$ Average background aerobic flora varied from 3.14 to $4.4 \mathrm{Log}$ cfu/mL for rehang rinsate and 2.5 to $2.28 \mathrm{Log}$ cfu/mL for post-chill rinsate.

${ }^{b}$ Number of positive samples detected by molecular method (MDA2SAL96 for LAMP and BAX ${ }^{\circledR}$ System PCR assay for Salmonella for PCR).

${ }^{\mathrm{c}}$ All samples were culturally confirmed as outlined in Figure 2.

${ }^{\mathrm{d}}$ Rinsates were inoculated with about 1 to 2 cfu/rinsate.

\subsubsection{Raw poultry products}

The average background aerobic flora in various products ranged from 1.3 to $5.9 \mathrm{Log}$ cfu/g (Table 4). One confirmed sample was not detected by the LAMP method (seasoned chicken breast) and two confirmed samples were not detected by the PCR method (chicken thighs and ground chicken). In addition, both methods had one unconfirmed presumptive positive result. Sensitivity for the detection of Salmonella in raw chicken products was 96.6\% for the LAMP method and $93.3 \%$ for the PCR method. The specificity was $97 \%$ for both methods.

The $3 \mathrm{M}^{\mathrm{TM}}$ Molecular Detection System uses an external amplification control, MDMC, to assess sample interference during the DNA isothermal amplification reaction. All matrices evaluated in this study for Salmonella detection resulted in a valid result with the MDMC indicating no inhibition of amplification reaction with any of the matrices tested in this study. Similarly, all matrices gave valid internal amplification result with the PCR method (BAX ${ }^{\circledR}$ System PCR assay 
for Salmonella).

Table 4. Comparison between the LAMP assay and the PCR method for the detection of Salmonella in raw poultry products

\begin{tabular}{|c|c|c|c|c|c|c|c|}
\hline \multirow{2}{*}{ Product $^{\mathrm{a}}$} & \multirow{2}{*}{$\begin{array}{l}\text { Background flora } \\
\quad \text { (Log cfu/g) }\end{array}$} & \multicolumn{3}{|c|}{ MDA2SAL96 } & \multicolumn{3}{|c|}{ BAX ${ }^{\circledR}$ System PCR assay for Salmonella } \\
\hline & & $\begin{array}{c}\text { Number of } \\
\text { samples }\end{array}$ & $\begin{array}{l}\text { Presumptive } \\
\text { result }^{\mathrm{b}}\end{array}$ & $\begin{array}{l}\text { Confirmed } \\
\text { result }^{\mathrm{c}}\end{array}$ & $\begin{array}{l}\text { Number of } \\
\text { samples }\end{array}$ & $\begin{array}{l}\text { Presumptive } \\
\text { result }^{\mathrm{b}}\end{array}$ & $\begin{array}{l}\text { Confirmed } \\
\text { result }^{\mathrm{c}}\end{array}$ \\
\hline Ground Turkey & 1.90 & 5 & 0 & 0 & 5 & 1 & 1 \\
\hline Marinated Tenders & 3.41 & 5 & 2 & 1 & 5 & 1 & 0 \\
\hline $\begin{array}{l}\text { Partially fried Chick- } \\
\text { en Patties }\end{array}$ & 6.36 & 5 & 2 & 2 & 5 & 1 & 1 \\
\hline $\begin{array}{l}\text { Partially fried Chick- } \\
\text { en Nuggets }\end{array}$ & 4.10 & 5 & 5 & 5 & 5 & 5 & 5 \\
\hline $\begin{array}{l}\text { Whole Bird without } \\
\text { giblets }\end{array}$ & 3.05 & 5 & 3 & 3 & 5 & 3 & 3 \\
\hline $\begin{array}{l}\text { Mechanically Sepa- } \\
\text { rated Chicken }\end{array}$ & 5.43 & 5 & 5 & 5 & 5 & 5 & 5 \\
\hline $\begin{array}{c}\text { Seasoned Chicken } \\
\text { Breast }\end{array}$ & 4.12 & 5 & 2 & 3 & 5 & 3 & 3 \\
\hline Plain Chicken Breast & 3.41 & 5 & 3 & 3 & 5 & 0 & 0 \\
\hline Chicken Tenders & 2.08 & 5 & 2 & 2 & 5 & 2 & 2 \\
\hline Chicken Thighs & 6.49 & 5 & 1 & 1 & 5 & 3 & 4 \\
\hline Ground Chicken & 3.65 & 5 & 1 & 1 & 5 & 2 & 3 \\
\hline Chicken Legs & 6.51 & 5 & 2 & 2 & 5 & 1 & 1 \\
\hline \multicolumn{2}{|c|}{ Total } & 60 & 28 & 28 & 60 & 27 & 28 \\
\hline
\end{tabular}

${ }^{a}$ Naturally contaminated or artificially inoculated samples with about 1 to 2 cfu/sample of Salmonella.

${ }^{b}$ Number of positive samples detected by molecular method (MDA2SAL96 for LAMP and BAX® System PCR assay for Salmonella for PCR).

${ }^{\mathrm{d}}$ Number of positive samples detected through culture (Figure 3). All samples were culturally confirmed regardless of presumptive results.

\subsubsection{Data analysis}

Analysis of dPOD for carcass rinses and raw poultry products showed that the detection of Salmonella spp. with the alternative LAMP method was not significantly different (95\% confidence interval) from the PCR method (Table 5).

Table 5. Probability of detection for unpaired comparison between the LAMP assay and the PCR method for the detection of Salmonella in various poultry matrices

\begin{tabular}{|c|c|c|c|c|c|c|c|c|c|}
\hline Matrix & Inoculation level $^{\mathrm{a}}$ & $\mathrm{N}^{\mathrm{b}}$ & $\begin{array}{l}\text { Confirmed positives } \\
\text { (PCR) }\end{array}$ & $\begin{array}{l}\text { Confirmed positives } \\
\text { (LAMP) }\end{array}$ & $\mathrm{POD}_{1}{ }^{\mathrm{c}}$ & $\mathrm{POD}_{2}{ }^{\mathrm{d}}$ & $\mathrm{dPOD}^{\mathrm{e}}$ & \multicolumn{2}{|c|}{$95 \% \mathrm{CI}^{\mathrm{f}}$} \\
\hline \multirow{2}{*}{ Carcass rinse (rehang) } & Natural & 10 & 2 & 1 & 0.2 & 0.1 & 0.1 & -0.24 & 0.42 \\
\hline & Low & 20 & 17 & 18 & 0.85 & 0.90 & 0.05 & -0.17 & 0.27 \\
\hline \multirow{2}{*}{ Carcass rinse (post-chill) } & Natural & 10 & 0 & 0 & 0 & 0 & 0 & -0.28 & 0.28 \\
\hline & Low & 20 & 19 & 19 & 0.95 & 0.95 & 0 & -0.19 & 0.19 \\
\hline Raw poultry products & Low/Natural & 60 & 27 & 28 & 0.45 & 0.47 & 0.02 & -0.16 & 0.19 \\
\hline
\end{tabular}

${ }^{\text {a }}$ Samples were inoculated with about 1 to 2 cfu/rinsate.

${ }^{\mathrm{b}} \mathrm{N}$ : Total number of samples analyzed with each of the method.

${ }^{\mathrm{C}} \mathrm{POD}_{1}$ : Probability of Detection for the PCR method.

${ }^{\mathrm{d}} \mathrm{POD}_{2}$ : Probability of Detection for the LAMP method.

edPOD: Differential between the $\mathrm{POD}_{1}$ and the $\mathrm{POD}_{2}$.

${ }^{f} 95 \%$ CI: LCL is the lower confidence level, UCL is the upper confidence level. If the confidence interval (CI) of a dPOD contains zero, then the difference is not statistically significant at the $5 \%$ level.

\section{Discussion}

LAMP uses a unique DNA polymerase for continuous DNA amplification that is resistant to matrix interference and inhibitors [15-24]. LAMP assays have the same or higher sensitivity compared to PCR assays and traditional culture methods in detecting foodborne pathogens such as Salmonella, Listeria spp., Listeria monocytogenes, Campylobacter 
and others from various food matrices [22-24, 26-33, 38, 39].

The LAMP assay (MDA2SAL96) used in this study provided next day results for detection of Salmonella in boot swab samples and was comparable (100\% agreement) to NPIP culture-based method. Hence, Salmonella can be detected by the LAMP method in boot swabs by direct enrichment in TT broth. Similarly, the LAMP assay was able to detect Salmonella in rehang and post-chill rinsates and raw poultry products and had higher or equivalent sensitivity and specificity to the PCR method.

In the initial culture screening of rinse and raw poultry products samples, some samples in both methods had atypical colonies on differential selective Salmonella agar. Further testing identified some atypical colonies as true Salmonella. This illustrates the challenge of isolating Salmonella from samples with competitive microflora as the associated microflora are also recovered in selective agars in addition to atypical phenotypes often exhibited by Salmonella [40]. Molecular methods based on amplification of specific DNA targets in pathogenic microorganisms are more specific than traditional method that is based on the use of selective agents or biochemical reactions. While colony confirmation is still relevant to laboratory testing, it is also important to recognize the higher specificity of molecular detection methods for pathogen testing [10-14].

Salmonella LAMP-bioluminescent assay has been successfully used for Salmonella detection in a variety of food samples [26-30, 32, 33]. The results from this study further validate that the LAMP-bioluminescent method is capable of detecting Salmonella in poultry related matrices with higher or equivalent sensitivity and specificity to the PCR method used in the study.

New performance standards adopted by USDA FSIS and other government agencies require specific and sensitive methods for detection of Salmonella in variety of poultry matrices. The LAMP method used in this study enables rapid detection of Salmonella in matrices commonly analyzed by the poultry industry. Recently, the USDA FSIS has updated Microbiology Laboratory Guidebook (MLG) to include $3 \mathrm{M}^{\mathrm{TM}}$ Molecular Detection Assays for Salmonella [35] and Listeria monocytogenes [41] giving further validation to LAMP assays as suitable alternative to PCR assays.

\section{Conclusions}

This study evaluated the performance of a LAMP-bioluminescent assay for the detection of Salmonella in primary production samples, poultry rinses and raw poultry products compared to a PCR method. Samples were tested after enrichment by LAMP-bioluminescent assay and PCR method. The alternative LAMP-bioluminescent assay was able to detect Salmonella in the various matrices tested and had higher or equivalent sensitivity and specificity to the PCR method used. There was no significant difference (95\% confidence interval) between the LAMP and PCR method for detection of Salmonella in poultry matrices tested. Hence, the Salmonella LAMP-bioluminescent assay is an acceptable alternative to the PCR method for rapid detection of Salmonella in variety of poultry matrices.

\section{Acknowledgements}

All the work was conducted at WBA Analytical Laboratories, Inc. under the direction of 3M Food Safety. The authors gratefully acknowledge WBA management for support and use of facilities to conduct the study.

\section{Conflict of interest}

The authors, R. Rajagopal, G. Lopez-Velasco and J. M. David are employees of 3M Food Safety which offers mul-

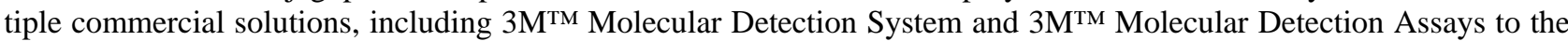
food industry. Melissa Sisemore and Jamie Goseland are employees of WBA Analytical Laboratory. WBA Analytical Laboratories provides microbiological and chemical analysis, product research and development, and technical services to its customers.

\section{References}

[1] CDC. (2021). Salmonella and food. https://www.cdc.gov/salmonella/index.html, Accessed October 25, 2021.

[2] Scallan, E., Hoekstra, R. M., Angulo, F. J., Tauxe, R. V., Widdowson, M. A., Roy, S. L., Jones, J. L., and Griffin, P. M. (2011). Foodborne illness acquired in the United States-major pathogens. Emerging infectious diseases, 17: 7-15. https://doi.org/10.3201/eid1701.p11101.

[3] Scharff, R. L. (2012). Economic burden from health losses due to foodborne illness in the United States. Journal of Food Protection, 75: 123-31.

[4] Russell, S. (2012). Controlling Salmonella in poultry production and processing, CRC press, Boca Raton, Florida.

[5] WHO. (2015). WHO estimates of the global burden of foodborne diseases: foodborne disease burden epidemiology reference 
group 2007-2015. http://apps.who.int/iris/bitstream/handle/10665/199350/9789241565165_eng.pdf?sequence=1\&ua=1, Accessed date: October 25, 2021.

[6] Rouger, A., Tresse, O., and Zagorec, M. (2017). Bacterial contaminants of poultry meat: sources, species, and dynamics. Microorganisms, 5: 50. https://doi.org/10.3390/microorganisms5030050.

[7] USDA FSIS. (2015). Changes to the Salmonella and Campylobacter verification testing program: proposed performance standards for Salmonella and Campylobacter in not-ready to-eat comminuted chicken and turkey products and raw chicken parts and related agency verification procedures and other changes to agency sampling. FSIS-2014-0023, Federal Register, 80: 3940-3950.

[8] USDA FSIS. (2019). Changes to the Campylobacter verification testing program: revised performance standards for Campylobacter in not-ready-to-eat comminuted chicken and turkey and related agency procedures. FSIS-2018-0044, Federal Register, 84: 38203-38210.

[9] USDA FSIS. (2021). USDA launches new effort to reduce Salmonella illnesses linked to poultry. Press release no. 0223.21. https://www.usda.gov/media/press-releases/2021/10/19/usda-launches-new-effort-reduce-salmonella-illnesses-linked-poultry, Accessed October 30, 2021.

[10] Jasson, V., Jacxsens, L., Luning, P., Rajkovic, A., and Uyttendaele, M. (2010). Alternative microbial methods: an overview and selection criteria. Food Microbiology, 27: 710-730. http://dx.doi.org/10.1016/j.fm.2010.04.008.

[11] Mangal, M., Bansal, S., Sharma, S. K., and Gupta, R. K. (2016). Molecular detection of foodborne pathogens: a rapid and accurate answer to food safety. Critical Reviews in Food Science and Nutrition, 56: 1568-1584. https://doi.org/10.1080/10408398.2013.782483.

[12] Park, S. H., Aydin, M., Khatiwara, A., Dolan, M. C., Gilmore, D. F., Bouldin, J. L., Ahn, S., and Ricke, S. C. (2014). Current and emerging technologies for rapid detection and characterization of Salmonella in poultry and poultry products. Food Microbiology, 38: 250-262. https://doi.org/10.1016/J.FM.2013.10.002.

[13] Souii, A., M’hadheb-Gharbi, M. B., and Gharbi, J. (2016). Nucleic acid-based biotechnologies for food-borne pathogen detection using routine time-intensive culture-based methods and fast molecular diagnostics. Food Science and Biotechnology, 25: 11-20. https://doi.org/10.1007/s10068-016-0002-1.

[14] Wiedmann, M., Wang, S., Post, L., and Nightingale, K. (2014). Assessment criteria and approaches for rapid detection methods to be used in the food industry. Journal of Food Protection, 77: 670-690. http://dx.doi.org/10.4315/0362-028X.JFP-13-138.

[15] Mori, Y. and Notomi, T. (2009). Loop-mediated isothermal amplification (LAMP): a rapid, accurate, and cost-effective diagnostic method for infectious diseases. Journal of Infection and Chemotherapy, 15: 62-69.

[16] Mori, Y., Kanda, H., and Notomi, T. (2013). Loop-mediated isothermal amplification (LAMP): recent progress in research and development. Journal of Infection and Chemotherapy, 19: 404-411.

[17] Notomi, T., Mori, Y., Tomita, N., and Kanda, H. (2015). Loop-mediated isothermal amplification (LAMP): principle, features, and future prospects. Journal of Microbiology, 53: 1-5. https://doi.org/10.1007/s12275-015-4656-9.

[18] Notomi, T., Okayama, H., Masubuchi, H., Yonekawa, T., Watanabe, K., Amino, N., and Hase, T. (2000). Loop-mediated isothermal amplification of DNA. Nucleic Acids Res., 28: E63.

[19] Kaneko, H., Kawana, T., Fukushima, E., and Suzutani, T. (2007). Tolerance of loop-mediated isothermal amplification to a culture medium and biological substances. Journal of Biochemistry and Biophysical Methods, 70: 499-501.

[20] Niessen, L., Luo, J., Denschlag, C., and Vogel, R. F. (2013). The application of loop-mediated isothermal amplification (LAMP) in food testing for bacterial pathogens and fungal contaminants. Food Microbiology, 36: $191-206$. http://dx.doi.org/10.1016/j.fm.2013.04.017.

[21] Plutzer, J. and Karanis, P. (2009). Rapid identification of Giardia duodenalis by loop-mediated isothermal amplification (LAMP) from faecal and environmental samples and comparative findings by PCR and real-time PCR methods. Parasitology Research, 104: 1527-1533.

[22] Yang, Q., Wang, F., Prinyawiwatkul, W., and Ge, B. (2014). Robustness of Salmonella loop-mediated isothermal amplification assays for food applications. Journal of Applied Microbiology, 116: 81-88. https://doi.org/10.1111/jam.12340.

[23] Yang, Q., Domesle, K. J., and Ge, B. (2018). Loop-mediated isothermal amplification for Salmonella detection in food and feed: current applications and future directions. Foodborne Pathogens and Disease, 15: 309-331. https://doi.org/10.1089/fpd.2018.2445.

[24] Domesle, K. J., Yang, Q., Hammack, T. S., and Ge, B. (2018). Validation of a Salmonella loop-mediated isothermal amplification assay in animal food. International Journal of Food Microbiology, 264: 63-76. https://doi.org/10.1016/j.ijfoodmicro.2017.10.020.

[25] Gandelman, O. A., Church, V. L., Moore, C. A. Kiddle, G., Carne, C. A., Parmar, S., Jalal, H., Tisi, L. C., and Murray, J. A. (2010). Novel bioluminescent quantitative detection of nucleic acid amplification in real-time. PLoS ONE, 5: e14155. https://doi.org/10.1371/journal.pone.0014155. 
[26] Bird, P., Flannery, J., Crowley, E., Agin, J. R., and Monteroso, L. (2016). Evaluation of the 3M"M Molecular Detection Assay (MDA) 2 - Salmonella for the detection of Salmonella spp. in select foods and environmental surfaces: collaborative study, first action 2016.01. Journal of AOAC International, 99: 980-997. https://doi.org/10.5740/jaoacint.16-0085.

[27] Hu, L., Ma, L. M., Zheng, S., He, X., Wang, H., Brown, E. W., Hammack, T. S., and Zhang, G. (2017). Evaluation of 3M Molecular Detection System and ANSR Pathogen Detection System for rapid detection of Salmonella from egg products. Poultry Science, 96: 1410-1418.

[28] Hu, L., Deng, X., Brown, E. W., Hammack, T. S., Ma, L. M., and Zhang, G. (2018). Evaluation of Roka Atlas Salmonella method for the detection of Salmonella in egg products in comparison with culture method, real-time PCR and isothermal amplification assays. Food Control, 94: 123-131.

[29] Huo, J., Huang, Y., and Rajagopal, R. (2021). Loop-mediated isothermal amplification vs. Guobiao standards method for detection of Salmonella in yoghurt and yoghurt-based drinks. International Journal of Dairy Science, 16: 90-97. https://dx.doi.org/10.3923/ijds.2021.90.97.

[30] Lim, H. S., Zheng, Q., Miks-Krajnik, M., Turner, M., and Yuk, H. G. (2015). Evaluation of commercial kit based on loop-mediated isothermal amplification for rapid detection of low levels of uninjured and injured Salmonella on duck meat, bean sprouts, and fishballs in Singapore. Journal of Food Protection, 78: 1203-1207.

[31] Rajagopal, R., Barnes, C. A., David, J. M., Goseland, J., and Goseland, J. (2021). Evaluation of a commercial loop-mediated isothermal amplification assay, $3 \mathrm{M}^{\mathrm{TM}}$ Molecular Detection Assay 2 - Campylobacter, for the detection of Campylobacter from poultry matrices. British Poultry Science, 62: 404-413. https://doi.org/10.1080/00071668.2021.1879992.

[32] Sarowska, J., Frej-Mądrzak, M., Jama-Kmiecik, A., Kilian, A., Teryks-Wołyniec, D., and Choroszy-Król, I. (2016). Detection of Salmonella in foods using a reference PN-ISO method and an alternative method based on loop-mediated isothermal amplification coupled with bioluminescence. Advances in Clinical and Experimental Medicine, 25: 945-950.

[33] Yang, Q., Domesle, K. J., Wang, F., and Ge, B. (2016). Rapid detection of Salmonella in food and feed by coupling loop-mediated isothermal amplification with bioluminescent assay in real-time. BMC Microbiology, 16 : 112. https://doi.org/10.1186/s12866-016-0730-7.

[34] NPIP. (2019). National Poultry Improvement Plan Program Standards, USDA Animal and Plant Health Inspection Service Veterinary Services. http://www.poultryimprovement.org/documents/ProgramStandardsA-E.pdf, Accessed October 25, 2021.

[35] USDA FSIS MLG 4.11. (2021). Isolation and identification of Salmonella from meat, poultry, pasteurized egg, and siluriformes (fish) products and carcass and environmental sponges. https://www.fsis.usda.gov/sites/default/files/media_file/ 2021-08/MLG-4.11.pdf, Accessed October 25, 2021.

[36] Eijkelkamp, J. M., Aarts, H. J. M., and van der Fels-Klerx, H. J. (2009). Suitability of rapid detection methods for Salmonella in poultry slaughterhouses. Food Analytical Methods, 2: 1-13. https://dx.doi.org/10.1007/s12161-008-9040-5.

[37] Wehling, P., LaBudde, R. A., and Nelson, M. T. (2011). Probability of Detection (POD) as a statistical model for the validation of qualitative methods. Journal of AOAC International, 94: 335-347.

[38] Hu, L., Ma, L. M., Zheng, S., He, X., Hammack, T. S., Brown, E. W., and Zhang, G. (2018). Development of a novel loop-mediated isothermal amplification (LAMP) assay for the detection of Salmonella ser. Enteritidis from egg products. Food Control, 88: 190-197.

[39] Zhang, G., Brown, E. W., and González-Escalona, N. (2011). Comparison of real-time PCR, reverse transcriptase real-time PCR, loop-mediated isothermal amplification, and the FDA conventional microbiological method for the detection of Salmonella spp. in produce. Applied and Environmental Microbiology, 77: 6495-6501. https://doi.org/10.1128/AEM.00520-11.

[40] Forstner, M. (2016). Salmonella flip book. Minnesota Department of Agriculture. https://www.fda.gov/downloads/Food/ FoodScienceResearch/RFE/UCM517352.pdf, Accessed date: October 25, 2021.

[41] USDA FSIS MLG 8.13. (2021). Isolation and identification of Listeria monocytogenes from red meat, poultry, ready-to-eat siluriformes (fish) and egg products, and environmental samples. https://www.fsis.usda.gov/sites/default/files/media_file/ 2021-09/MLG-8.13.pdf, Accessed October 25, 2021. 